\section{Arrhythmogenic potential of dopexamine hydrochloride during hydrochloride during
halothane anaesthesia in dogs}

Steven M. Neustein MD, Ivan Dimich MD, Ian Sampson MD, Ali Sadeghi MD,

Craig Mezrow BS, Howard Shiang vMD
Dopexamine hydrochloride (Dopacard ${ }^{\circledR}$ ) is the novel synthetic catecholamine designed for use in the acute management of a low cardiac output status. In addition to dopaminergic receptor stimulation, dopexamine hydrochloride is a potent $\beta_{2}$ adrenoreceptor agonist with negligible direct $\beta_{1}$ and no alpha adrenergic effect. The objective of this study was to compare the arrhythmogenic effects of dopexamine hydrochloride and dopamine in dogs anaesthetized with halothane (1.2 MAC). The starting dose for dopexamine hydrochloride was 3.5 $\mu \mathrm{g} \cdot \mathrm{kg}^{-1} \cdot \mathrm{min}^{-1}$ and for dopamine was $5 \mu \mathrm{g} \cdot \mathrm{kg}^{-1} \cdot \mathrm{min}^{-1}$. Concentrations of the drugs were increased until four or more premature ventricular contractions within 15 seconds were produced. All dogs developed ventricular tachycardia when dopamine was administered in concentrations ranging between 18-20 $\mathrm{\mu g} \cdot \mathrm{kg}^{-1} \cdot \mathrm{min}^{-1}$. Unlike dopamine, dopexamine hydrochloride even at concentrations as high as 50 $\mu \mathrm{g} \cdot \mathrm{kg}^{-1} \cdot \mathrm{min}^{-1}$ did not induce any atrial or ventricular ectopic beats. Lack of $\beta_{l}$ and alpha adrenergic agonist effects is a likely explanation for low arrhythmogenicity of dopexamine hydrochloride. Both drugs increase cardiac output; dopexamine hydrochloride primarily by a dose-related increase in heart rate and increased afterload. At the maximal concentration dopexamine hydrochloride increased heart rate from 114 to 150 beat $\cdot \mathrm{min}^{-1}$, mean arterial pressure decreased from $81 \mathrm{~mm} \mathrm{Hg}$ to $45 \mathrm{mmHg}$ and $S V R$ decreased from 2418 to 962

\section{Key words}

ANAESTHETICS, VOLATILE: halothane;

HEART: arrhythmias;

SYMPATHETIC NERVOUS SYSTEM: dopexamine, dopamine.

From the departments of Anesthesiology and Cardiovascular Surgery, Mount Sinai School of Medicine, of the City University of New York, NY.

Presented in part at the International Anesthesia Research Society 67th Congress, 1993.

Address correspondence to: Ivan Dimich, Department of Anesthesiology, Mount Sinai Medical Center, 1 Gustave L. Levy Place, Box 1010, New York, NY 10029-6574. Accepted for publication 28th February, 1994. dyne $\cdot \mathrm{sec}^{-1} \mathrm{~cm}^{-5}$. Myocardial contractility increased only moderately, as evaluated by $d P / d t$, which increased from 1290 to $1696 \mathrm{~mm} \mathrm{Hg} \cdot \mathrm{sec}^{-1}$. Dopamine had a more marked inotropic effect: the $d P / d t$ increased, at the maximal concentration, from 1480 to $2570 \mathrm{~mm} \mathrm{Hg} \cdot \mathrm{sec}^{-1}$. Dopamine also produced vasoconstriction: $S V R$ increased from 2325 to 2683 dyne $\cdot \mathrm{sec} \cdot \mathrm{cm}^{-5}$ and mean arterial pressure from $86 \mathrm{mmHg}$ to $110 \mathrm{mmHg}$. In conclusion, dopexamine hydrochloride is less arrhythmogenic than dopamine, has less of an inotropic effect, and a greater effect on afierload.

Lhydrochlorure de dopexamine (Dopacard ${ }^{\circledR}$ ) est une nouvelle catécholamine synthétique destinée au traitement des états de bas débit cardiaque. En plus de stimuler les récepteurs dopaminergiques, lhydrochlorure de dopexamine est un agoniste adrénorécepteur $\beta_{2}$ puissant avec effets directs $\beta_{1}$ négligeables mais sans effets alpha-adrénergiques. Cette étude vise à comparer les effets arhythmogènes de l'hydrochlorure de doxepamine avec la dopamine sur des chiens anesthésiés à l'halothane (1,2 MAC). La dose initiale dhydrochlorure de dopexamine est de 3,5 $\mu \mathrm{g} \cdot \mathrm{kg}^{-1} \cdot \mathrm{min}^{-1}$ et de dopamine de 3,5 $\mu \mathrm{g} \cdot \mathrm{kg}^{-1} \cdot \mathrm{min}^{-1}$. La concentration des drogues a été augmentée jusqu'à l'apparition de quatre contractions prématurées ou plus en deçà de 15 secondes. Tous les chiens ont développé de la tachycardie ventriculaire pendant l'administration de dopamine à des doses se situant entre $18 \mathrm{et} 20 \mu \mathrm{g} \cdot \mathrm{kg}^{-1} \cdot \mathrm{min}^{-1}$. Contrairement à la dopamine, lhydrochlorure de dopexamine n'a pas provoqué de battements ectopiques auriculaires ou ventriculaires même à des concentrations aussi élevées que 50 $\mu \mathrm{g} \cdot \mathrm{kg}^{-1} \cdot \mathrm{min}^{-1}$. L'absence d'effets $\beta_{l}$ et agonistes alphaadrénergiques constitue une explication plausible pour la faible arrythmogénécité de lhydrochlorure de dopexamine. Les deux drogues augmentent le débit cardiaque; lhydrochlorure de dopexamine principalement par augmentation en rapport avec la dose de la fréquence cardiaque et une baisse de la postcharge. A la concentration maximale d'hydrochlorure de dopexamine, la fréquence cardiaque augmente de 114 à 150 $b \cdot$ min $^{-1}$, la pression artérielle moyenne baisse de 81 à 45 $\mathrm{mmHg}$ et la résistance vasculaire systémique (RVS) baisse de 2418 à 962 dyne $\cdot \mathrm{sec}^{-1} \cdot \mathrm{cm}^{-5}$. La contractilité myocardique 
mesurée par le dP/dt n'augmente que modérément de 1290 à $1696 \mathrm{~mm} \mathrm{Hg} \cdot \mathrm{sec}^{-1}$. Par contre, la dopamine a un effet inotrope plus marqué: le dP/dt augmente de 1480 à 2570 $\mathrm{mmHg} \cdot \mathrm{sec}^{-1}$ à la concentration maximale. La dopamine produit aussi de la vasoconstriction: la RVS augmente de 2325 à 2683 dyne $\cdot \mathrm{sec} \cdot \mathrm{cm}^{-5}$ et la pression artérielle moyenne de $68 \mathrm{~mm} \mathrm{Hg}$ à $110 \mathrm{mmHg}$. En conclusion, l'hydrochlorure de dopexamine est moins arythmogène que la dopamine, a moins d'effets inotropes mais agit plus sur la post-charge.

Dopexamine hydrochloride (Dopacard) is a short-acting analogue of dopamine, with a pharmacological profile that offers some advantages over dopamine and dobutamine in the treatment of severe congestive heart failure. It is a dopaminergic receptor agonist and a $\beta_{2}$-adrenoreceptor agonist devoid of $\alpha$ and direct $\beta_{1}$ receptor activity. ${ }^{1}$ This profile offers some advantages over other inotropes in terms of a greater reduction in afterload and less positive inotropic effect. ${ }^{2}$ Strong positive inotropy is usually mediated by $\beta_{1}$-adrenoreceptor agonism and may be undesirable because of its effect on myocardial energy requirements and arrhythmogenicity., ${ }^{1,2}$

In both conscious and anaesthetized dogs, dopexamine hydrochloride (in doses ranging from 12.3 to 40 $\mu \mathrm{g} \cdot \mathrm{kg}^{-1} \cdot \mathrm{min}^{-1}$ ) causes a dose-related decrease in blood pressure and peripheral vascular resistance together with a moderate increase in heart rate and myocardial contractility. In clinical studies of patients with severe congestive heart failure, ${ }^{1-3}$ dopexamine hydrochloride improved ventricular performance but this effect diminished with long-term infusion. . $^{4}$

The parenteral administration of catecholamines (epinephrine, dopamine, or dobutamine) during halothane anaesthesia can initiate malignant ventricular tachycardia. ${ }^{8}$ Although the exact mechanism by which halothane sensitizes the myocardium to catecholamines is poorly understood, it has been assumed that stimulation of betaadrenergic $\left(\beta_{1}\right.$ and $\left.\beta_{2}\right)$ and/or alpha adrenergic receptors is mainly responsible for these arrhythmias. ${ }^{8-11}$

The purpose of this study was to determine whether infusion of dopexamine hydrochloride, given in increasing concentration, would induce ventricular arrhythmias during halothane anaesthesia in dogs. Haemodynamic and arrhythmogenic effects of dopexamine hydrochloride were compared with those produced by an infusion of dopamine. Halothane was used because the amount of adrenergic agent that will elicit such arrhythmias is less during halothane anaesthesia than with other presently used inhalational anaesthetics. Dogs were used because most of the previous experiments on catecholamineinduced arrhythmias during halothane anaesthesia were done using the dog model.

\section{Methods}

Following approval of the protocol by the Institutional Animal Investigation Committee, eight mongrel dogs of either sex, weighing $18-20 \mathrm{~kg}$, were anaesthetized with thiopentone $10 \mathrm{mg}^{-1} \cdot \mathrm{kg}^{-1} i \mathrm{v}$. Tracheal intubation was performed and then mechanical ventilation instituted to maintain pH 7.35 \pm 0.5 , and $\mathrm{PaCO}_{2} 35-40 \mathrm{mmHg}$. Anaesthesia was maintained with halothane in oxygen at an end tidal concentration of $1 \%(1.2 \mathrm{MAC})$, which was continuously monitored using an airway gas analyzer (Datex 254, Datex/Puritan Bennet Co., Wilmington, MA).

Oesophageal temperature was servo-controlled between $37-39^{\circ} \mathrm{C}$ with a heating lamp. Normovolaemia was maintained by infusing lactated Ringer's solution via an intravenous cannula at a rate of $4 \mathrm{ml} \cdot \mathrm{kg}^{-1} \cdot \mathrm{hr}^{-1}$. A 14-gauge polyurethane cannula was inserted into the femoral artery to measure aortic pressure and for obtaining intermittent arterial blood gas and electrolyte measurements. A 7.5 F thermodilution pulmonary artery catheter was placed in the pulmonary artery via the femoral vein.

Aortic, pulmonary artery, and central venous pressures were continuously monitored and intermittent pulmonary artery capillary wedge pressures (PACWP) were determined. Intermittent thermodilution cardiac output (CO) measurements were obtained, and recorded as the mean of three measurements.

A micromanometer-tipped catheter (Millar Instrument Model PC 350) was used to measure $\mathrm{dP} / \mathrm{dt}$ and left ventricular (LV) pressure. The catheter was inserted into the left ventricle via the left atrium using a left thoracotomy incision. Cardiac index (CI), stroke volume index (SVI), systemic vascular resistance (SVR), and pulmonary vascular resistance (PVR) were calculated using the standard formulas.

Following $60 \mathrm{~min}$ of haemodynamic stability during halothane anaesthesia, either dopamine or dopexamine hydrochloride was infused in a randomized order with an infusion pump. The starting dose for dopexamine hydrochloride was $3.5 \mu \mathrm{g} \cdot \mathrm{kg}^{-1} \cdot \mathrm{min}^{-1}$ and for dopamine was $5 \mu \mathrm{g} \cdot \mathrm{kg}^{-1} \cdot \mathrm{min}^{-1}$. Drugs were given in standardized logarithmically spaced increasing doses for dopamine $\left(5.0,6.1,7.4,9.0\right.$ etc. $\left.\mu \mathrm{g} \cdot \mathrm{kg}^{-1} \cdot \mathrm{min}^{-1}\right)$ and for dopexamine hydrochloride $(3.5,4.3,5.2,6.4$ etc. $\left.\mu \mathrm{g} \cdot \mathrm{kg}^{-1} \cdot \mathrm{min}^{-1}\right)$.The arrhythmogenic dose was defined as the dose $\left(\mu \mathrm{g} \cdot \mathrm{kg}^{-1} \cdot \mathrm{min}^{-1}\right)$ which produced four or more premature ventricular contractions within $15 \mathrm{sec}$. In the absence of arrhythmias during three minutes of drug infusion, the infusion was terminated for ten minutes, and then the next higher dose was repeated until the arrhythmogenic dose was reached.

After establishment of the arrhythmogenic dose and a 30 min recovery period, the arrhythmogenic dose of 
the second drug was determined, by the same method. The sequence of the administered drugs was altered in each experiment.

\section{Statistical methods}

All data are presented as mean \pm SD of the mean. Significant changes among multiple observations for each variable were detected by two-way analyses of variance, and individual differences between observations were then determined using a paired $t$ test.

\section{Results}

All dogs, during 1.2 MAC halothane anaesthesia, developed ventricular tachycardia when dopamine was administered at concentrations ranging between 18-20 $\mu \mathrm{g} \cdot \mathrm{kg}^{-1} \cdot \mathrm{min}^{-1}$. Unlike dopamine, dopexamine hydrochloride even at concentrations as high as $50 \mu \mathrm{g} \cdot \mathrm{kg}^{-1} \cdot \mathrm{min}^{-1}$ failed to induce any cardiac arrhythmias. The haemodynamic effects of the maximum dose of dopexamine hydrochloride and dopamine are presented in the Table. Dopexamine hydrochloride produced a dose-related decrease in blood pressure and total peripheral resistance, with increases in cardiac output, contractility $(\mathrm{dP} / \mathrm{dt})$ and heart rate. In contrast, dopamine increased both blood pressure and heart rate and produced a dose-related increase in contractility $(\mathrm{dP} / \mathrm{dt})$.

\section{Discussion}

There is a concern that inotropic stimulation as a means of treating heart failure may cause deterioration of an already damaged myocardium. ${ }^{1,2}$ An alternative approach to the management of congestive heart failure has been successfully established with the use of vasodilatation that improves cardiac output by reducing afterload. ' One mechanism for afterload reduction is stimulation of $\beta_{2}$ adrenoreceptors. ${ }^{3,5}$ The $\beta_{2}$ adrenoreceptors are located in arterial vascular smooth muscle and mediate vasodilatation. Recently, it has been recognized that the $\beta_{\mathbf{2}}$ adrenoreceptors also coexist in the heart with $\beta_{1}$ adrenoreceptors where they have both inotropic and chronotropic actions in response to catecholamine stimulation. ${ }^{12,13}$ The $\beta_{2}$ adrenoreceptors may assume increased importance in the late stage of congestive heart failure because of a decrease in density and responsiveness of cardiac $\beta_{1}$ adrenoreceptors. This down regulation does not occur with $\beta_{2}$ adrenoreceptors. ${ }^{12,13}$

Dopexamine hydrochloride produces afterload reduction as a result of $\beta_{2}$ adrenoreceptor stimulation, but in contrast to other inotropes, has minimal effect at $\beta_{1}$ and $\alpha$ andrenoreceptors.

Clinical trials in patients with acute exacerbation of chronic severe heart failure and in acute cardiac failure following myocardial infarction indicate that dopexamine
TABLE The haemodynamic effects of the maximally used dose of dopexamine hydrochloride and dopamine (Mean \pm SD).

\begin{tabular}{|c|c|c|}
\hline & Dopamine* & $\begin{array}{l}\text { Dopexamine } \\
\text { hydrochloride } \dagger\end{array}$ \\
\hline \multicolumn{3}{|c|}{ Heart rate (beats $\cdot \min ^{-1}$ ) } \\
\hline Baseline & $118.1 \pm 3$ & $114.6 \pm 4$ \\
\hline Max infusion & $131.8 \pm 5$ & $150.1 \pm 6 \ddagger$ \\
\hline \multicolumn{3}{|c|}{ Systolic pressure $(\mathrm{mmHg})$} \\
\hline Baseline & $109.5 \pm 4$ & $105.6 \pm 3$ \\
\hline Max infusion & $170.8 \pm 6 \ddagger$ & $70.3 \pm 3+\S$ \\
\hline \multicolumn{3}{|c|}{ Diastolic pressure (mmHg) } \\
\hline Baseline & $72.6 \pm 3$ & $69.1 \pm 4^{*}$ \\
\hline Max infusion & $90.5 \pm 4$ & $32.6 \pm \pm \$$ \\
\hline \multicolumn{3}{|c|}{ Mean arterial pressure (mmHg) } \\
\hline Baseline & $86.1 \pm 4$ & $81.0 \pm 5$ \\
\hline Max infusion & $110.8 \pm 3$ & $45.1 \pm 4 \ddagger \S$ \\
\hline \multicolumn{3}{|c|}{$\mathrm{dP} / \mathrm{dt} \mathrm{mmHg} \cdot \mathrm{sec}^{-1}$} \\
\hline Baseline & $1480 \pm 30$ & $1290 \pm 28$ \\
\hline Max infusion & $2570 \pm 42 \ddagger$ & $1690 \pm 36$ \\
\hline \multicolumn{3}{|c|}{ Cardiac Index $\left(\mathrm{L} \cdot \mathrm{min}^{-1} \cdot \mathrm{m}^{-2}\right)$} \\
\hline Baseline & $2.75 \pm 0.4$ & $2.4 \pm 0.3$ \\
\hline Max infusion & $3.7 \pm 0.5$ & $5.2 \pm 0.4 \ddagger$ \\
\hline \multicolumn{3}{|c|}{ Stroke volume index $\left(\mathrm{ml} \cdot \mathrm{m}^{-2}\right)$} \\
\hline Baseline & $30 \pm 1$ & $24.5 \pm 2$ \\
\hline Max infusion & $38.3 \pm 2$ & $31.8 \pm 1$ \\
\hline \multicolumn{3}{|c|}{$\begin{array}{l}\text { Systemic vascular resistance } \\
\text { dyne } \cdot \mathrm{sec} \cdot \mathrm{cm}^{-5}\end{array}$} \\
\hline Baseline & $2325 \pm 32$ & $2418 \pm 28$ \\
\hline Max infusion & $2683.3 \pm 36$ & $962.5 \pm 35 \neq \S$ \\
\hline
\end{tabular}

*Maximal infusion, dopamine $18-20 \mu \mathrm{g} \cdot \mathrm{kg}^{-1} \cdot \mathrm{min}^{-1}$.

$\dagger$ Maximal infusion, dopexamine $50 \mathrm{\mu g} \cdot \mathrm{kg}^{-1} \cdot \mathrm{min}^{-1}$.

$\ddagger P<0.05$ when comparing baseline with maximal infusion value, same group.

$\S P<0.05$ when comparing maximal infusion values dopamine vs. dopexamine group.

hydrochloride produces beneficial systemic vasodilatation coupled with an improvement in myocardial function. ${ }^{5,6,14}$ Dosages used in these studies ranged from 1 to 8 $\mu \mathrm{g} \cdot \mathrm{kg}^{-1} \cdot \min ^{-1}$. Santman ${ }^{7}$ successfully used dopexamine hydrochloride to treat low cardiac output after cardiac surgery. In this study dopexamine hydrochloride was used over $24 \mathrm{hr}$ in doses from 1 to $4 \mu \mathrm{g} \cdot \mathrm{kg}^{-1} \cdot \mathrm{min}^{-1}$. Parrat et al. ${ }^{15}$ reported that dopexamine hydrochloride was associated with a lower incidence of ventricular arrhythmias following coronary artery ligation in animal models of myocardial ischaemia. This lower arrhythmogenic potential of dopexamine hydrochloride was explained by its relative lack of activity at $\beta_{1}$ adrenoreceptors which have been implicated in dysrhythmias induced by other ca- 
techolamines. Studies of isolated cardiac conduction tissue also suggest that under ischaemic conditions dopexamine hydrochloride has a class I-like antiarrhythmic effect. ${ }^{15}$

Our haemodynamic data revealed that both drugs, dopamine and dopexamine hydrochloride, augmented cardiac performance (Table) as displayed by increased cardiac output and LV dP/dt. The mechanism by which this was achieved was different. In the case of dopexamine hydrochloride, the increase in cardiac output resulted mainly from the decrease in systemic blood pressure (decreased afterload) and from the resultant increased heart rate. There was also a moderate increase in myocardial contractility as assessed by the moderate increase in LV $\mathrm{dP} / \mathrm{dt}$. In contrast, dopamine produced an increase in cardiac output and stroke volume index apparently through a combination of increased heart rate and contractility $(\mathrm{dP} / \mathrm{dt})$. It appears that dopamine increased cardiac performance predominantly through a positive inotropic effect. Similar haemodynamic data from anaesthetized dogs were reported by other investigations. $1,3,15$

Despite extensive investigation, the exact mechanism by which catecholamines induce arrhythmias during halothane anaesthesia has not been established. Katz et al. ${ }^{8,11}$ reported that stimulation of myocardial beta adrenoreceptors $\beta_{1}$ and $\beta_{2}$ was mainly responsible for these arrhythmias. Hayashi et al. ${ }^{9}$ have shown in dogs that the cardiac $\beta_{1}$ adrenoreceptors play an important role in the genesis of myocardial sensitization by halothane, whereas the role of the $\beta_{2}$ receptor is insignificant. Maze et al. ${ }^{10}$ used selective adrenergic receptor blockade in dogs anaesthetized with halothane and exposed to epinephrine to determine whether ventricular arrhythmias were associated with $\alpha$ or $\beta$ receptor activity. These results supported a predominant role for alpha-adrenergic agonists in epinephrine-halothane arrhythmias. This is in contrast to the widespread clinical observation of a higher incidence of these arrhythmias after the administration of a beta agonist. ${ }^{1,4}$ Furthermore Zuckerman et al. ${ }^{16}$ demonstrated little arrhythmogenic activity in myocardial cells exposed to an alpha-adrenergic agonist with or without halothane. Beta adrenergic agonist exposure resulted in more arrhythmogenic activity.

Our data confirmed that cardiac $\beta_{2}$ adrenoreceptors do not play an important role in the genesis of myocardial sensitization to halothane. Therefore, treatment with $\beta_{1}$ blockers is preferable to $\beta_{2}$ or non-selective $\beta$ blockers for the treatment of catecholamine-halothane ventricular arrhythmias. ${ }^{17}$

Elevation in arterial blood pressure and heart rate has also been regarded as an important factor in the development of these arrhythmias by some investigators. ${ }^{18,19}$
They suggested that treatment of elevated blood pressure and heart rate should be a primary goal in the prevention of epinephrine-halothane arrhythmias. Reynolds et al. ${ }^{18}$ reported that artificial elevation of the blood pressure during an infusion of a subthreshold dose of epinephrine could induce ventricle bigeminy which could be aborted by a sudden reduction of blood pressure. However, Maze et al. ${ }^{10}$ observed that while sodium nitroprusside prevented an increase in the blood pressure by epinephrine during halothane anaesthesia, it did not exert any antiarrhythmic activity. This indicates that hypertension induced by dopamine in our study is not solely responsible for ventricular arrhythmias.

Reynold et al. ${ }^{18}$ also reported acceleration of the heart rate with sinus tachycardia prior to the onset of arrhythmias. Atrial pacing at a similarly increased rate during a subthreshold infusion of epinephrine also induced ventricular arrhythmias. In our study we also observed acceleration of heart rate, especially following the administration of dopexamine hydrochloride, but this tachycardia did not initiate any ventricular arrhythmias. Furthermore, Hayashi et al. ${ }^{20}$ demonstrated in the intact dog preparation that the increase in heart rate alone was not an important factor in the aetiology of epinephrinehalothane-induced arrhythmias.

In conclusion, dopexamine hydrochloride unlike dopamine and other catecholamines produces no atrial or ventricular arrhythmias in dogs anaesthetized with halothane. The lower arrhythmogenic potential of dopexamine may result from its relative lack of activity at $\beta_{1}$ receptors which have been implicated in arrhythmias induced by other catecholamines.

\section{Acknowledgement}

The authors thank Fisons Pharmaceutical for supplying dopexamine hydrochloride.

\section{References}

1 Smith $G W, O^{\prime}$ Connor $S E$. An introduction to the pharmacologic properties of Dopacard (dopexamine hydrochloride). Am J Candiol 1988; 62: 9C-16C.

2 Foulds RA. Clinical development of dopexamine hydrochloride (Dopacard) and an overview of its hemodynamic effects. Am J Cardiol 1988; 62: 41C-5C.

3 Ghosh S, Gray B, Oduro A, Latimer RD. Dopexamine hydrochloride: pharmacology and use in low cardiac output states. J Cardiothorac Vasc Anesth 1991; 5: 382-9.

4 Jackson NC, Taylor SH, Frais MA. Hemodynamic comparison of dopexamine hydrochloride and dopamine in ischemic left ventricular dysfunction. Am J Cardiol 1988; 62: 73C-7C.

5 Baumann G, Felix $S B$, Filcek $S A$. Usefulness of dopexamine hydrochloride versus dobutamine in chronic conges- 
tive heart failure and the effects on hemodynamics and urine output. Am J Cardiol 1990; 65: 748-54.

6 Colardyn FA, Vandenbogaerde JF. Use of dopexamine hydrochloride in intensive care patient with low-output left ventricular heart failure. Am J Cardiol 1988; 62: 30C-6C.

7 Santman FW. Prolonged infusion of varied doses of dopexamine hydrochloride for low cardiac output after cardiac surgery. J Cardiothorac Vasc Anesth 1992; 6: 568-72.

$8 \mathrm{Katz} R L$, Epstein $R A$. The interaction of anesthetic agents and adrenergic drugs to produce cardiac arrhythmias. Anesthesiology 1968: 29; 763-89.

9 Hajashi Y, Sumikawa K, Fukumitsu K, Tashiro C, Yoshiya $I$. Combination of action of cardiac $\beta_{1}$ and $\beta_{2}$ adrenoreceptors on induction arrhythmias during halothane anesthesia in dogs. Anesthesiology 1989: 71; A517.

10 Maze $M$, Smith $C M$. Identification of receptor mechanism mediating epinephrine-induced arrhythmias during halothane anesthesia in the dog. Anesthesiology 1983; 59: 322-6.

11 Katz RL, Lord CO, Eakins KE. Anaesthetic-dopamine cardiac arrhythmias and their prevention by beta adrenergic blockade. J Pharmacol Exp Ther 1967; 158: 40-5.

12 Brodde $O E$. The functional importance of beta ${ }_{1}$ and beta 2 adrenoreceptors in the human heart. Am J Cardiol 1988: 62; 24C-9C.

13 Lang RM, Borow KM, Neuman A, et al. Role of the beta $_{2}$ adrenoreceptor in mediating positive inotropic activity in the failing heart and its relation to the hemodynamic actions of dopexamine hydrochloride. Am J Cardiol 1988; 62: 46C-52C.

14 De Marco T, Kwasman M, Lau D, Chatterjee K. Dopexamine hydrochloride in chronic congestive heart failure with improved cardiac performance without increased metabolic cost. Am J Cardiol 1988; 62: 57C-62C.

15 Parrat JR, Wainwright CL, Fagbemi $O$. Effect of dopexamine hydrochloride in the early stages of experimental myocardial infarction and comparison with dopamine and dobutamine. Am J Cardiol 1988; 62: 18C-23C.

16 Zuckerman $R L$, Wheeler DM. The effect of halothane on arrhythmogenic responses induced by sympathomimetic agents in single rat heart cells. Anesth Analg 1990; 70: S450.

17 Dimich I, Lingham $R$, Narang J, Sampson I, Shiang $H$. Esmolol prevents and suppresses arrhythmias during halothane anaesthesia in dogs. Can J Anaesth 1992; 39: 83-6.

18 Reynolds $A K$. Cardiac arrhythmias in sensitized hearts primary mechanisms involved. Res Commun Chem Pathol Pharmacol 1983; 40: 3-14.

19 Reynolds AK, Chiz JF, Pasquet AF. Halothane and methoxyflurane - a comparison of their effects on cardiac pacemaker fibers. Anesthesiology 1970; 33: 602-10.

20 Hayashi Y, Sumikawa K, Yamatodani A, Kamibayashi T, Kuro M, Yashiya I. Myocardial epinephrine sensitization with subanesthetic concentrations of halothane in dogs. Anesthesiology 1991; 74: 134-7. 